KEYWORDS

Exports

Imports

Manufactures

China

Data analysis

Mathematical models

Trade statistics
Roberto Álvarez E.

Senior Economist,

Financial Policy Division,

Central Bank of Chile

- ralvarez@bcentral.cl

Eugenio Figueroa B.

Professor, Department of

Economics,

University of Chile

- efiguero@econ.uchile.cl

María Pía Figueroa Z.

Research Associate,

Department of Economics,

University of Chile

- mfiguero@fen.uchile.cl

Macarena Palma E.

Research Associate,

Department of Economics,

University of Chile

- mpalma@fen.uchile.cl

\section{Determinants of world manufacturing exports to China, 1990-2006}

\author{
Roberto Alvarez E., Eugenio Figueroa B., \\ María Pia Figueroa Z. and Macarena Palma E.
}

$\mathrm{T}$

his paper studies the determinants of manufacturing exports to China. Data from 79 countries for the 1990-2006 period and estimates of gravity equations are used to analyse the effects of countries' factor endowment, geographical characteristics and degree of economic openness. The results are consistent with the factor abundance model and reveal that economies with a larger human capital endowment export a greater volume of manufactures to China. Having a large economy and being geographically close to China also make a country more likely to export manufactures to it. The results do not indicate that other characteristics of countries, such as openness to trade or an outlet to the sea, play an important role; nor does the endowment per worker of land or capital. The implications of this study should be of interest to economies seeking to benefit from the remarkable dynamism of the Chinese economy by diversifying their exports into manufactures. 


\section{I}

\section{Introduction}

The strong economic growth experienced by China over the past 20 years has led to a large rise in demand for foreign goods and services. In contrast to its low level of economic integration in the past, the country has now become one of the leading actors in global economic development, accounting for some $15 \%$ of international trade in manufactures (Lehmann, Moreno and Jaramillo, 2007). If this dynamism is sustained, there will be a substantial rise in exports from the rest of the world to China, particularly of goods for which its economy lacks comparative advantages or the prospect of developing them.

Exports from developing countries to China currently consist mainly of raw materials, but the great size of the Chinese economy and the scale of the growth expected there could make it a very attractive market for manufactured goods exports. In view of this, the purpose of the present study is to analyse the determinants of manufacturing exports to China. Using data from 79 countries over the 1990-2006 period, it first describes the main stylized facts about manufacturing exports to the country and then uses a gravity model to examine their determinants. In particular, it analyses the role played by factor endowment, geographic variables, openness to international trade and economy size.
This provides a basis for identifying which countries, especially among the less developed, might have the best chance of becoming substantial suppliers of Chinese manufacturing imports.

Although there are a number of studies on the consequences of China's entry into world trade, ${ }^{1}$ few address the question of how other developing nations might take advantage of this opportunity to shift their specialization structure towards manufactures. This is particularly important for commodity exporters, which tend to be affected by fluctuations in the global economy and could reduce this vulnerability if they had a more diversified export structure. To an extent, then, our study has a similar purpose to that of Mesquita Moreira (2007), who identified China as a strong competitor to Latin America in manufacturing trade. In contrast to the analysis performed by that author, however, we explore whether China can become a major destination market for manufacturing exports, and we study a larger sample of countries.

This paper is divided into five sections. Following this introduction, it analyses the evolution of manufacturing exports to China. The third section describes information sources and specifications, the fourth presents and discusses the results of the gravity model estimates and the last offers conclusions.

\section{II}

\section{Exporting to China}

China's dramatic entry into world markets has been an event of great importance because of the country's economic dynamism, reflected in growth rates of over $9 \%$ a year for the past 17 years. Following a long period of commercial isolation, Deng Xiaoping began an economic reform process that culminated in a significant

$\square$ The authors are grateful for the valuable comments of an anonymous referee, for the suggestions received during a research seminar at the Department of Economics of the University of Chile and for the efficient work of Waldo Riveras. Any errors that may remain are entirely their own. lowering of trade barriers. Chinese trade with the rest of the world has grown substantially as a result.

As figure 1 shows, Chinese imports rose from US\$ 53 billion to just over US\$ 790 billion between 1990 and 2006, with manufacturing imports rising from US\$ 41 billion to just over US\$ 570 billion in the same period (figure 2).

\footnotetext{
${ }^{1}$ See the recent studies by Blázquez-Lidoy, Rodríguez and Santiso (2006), Claro (2006), Devlin, Estevadeordal and Rodríguez-Clare (2006) and Rosales and Kuwayama (2007).
} 
FIGURE 1

China: total imports by value, 1990-2006

(Billions of dollars)

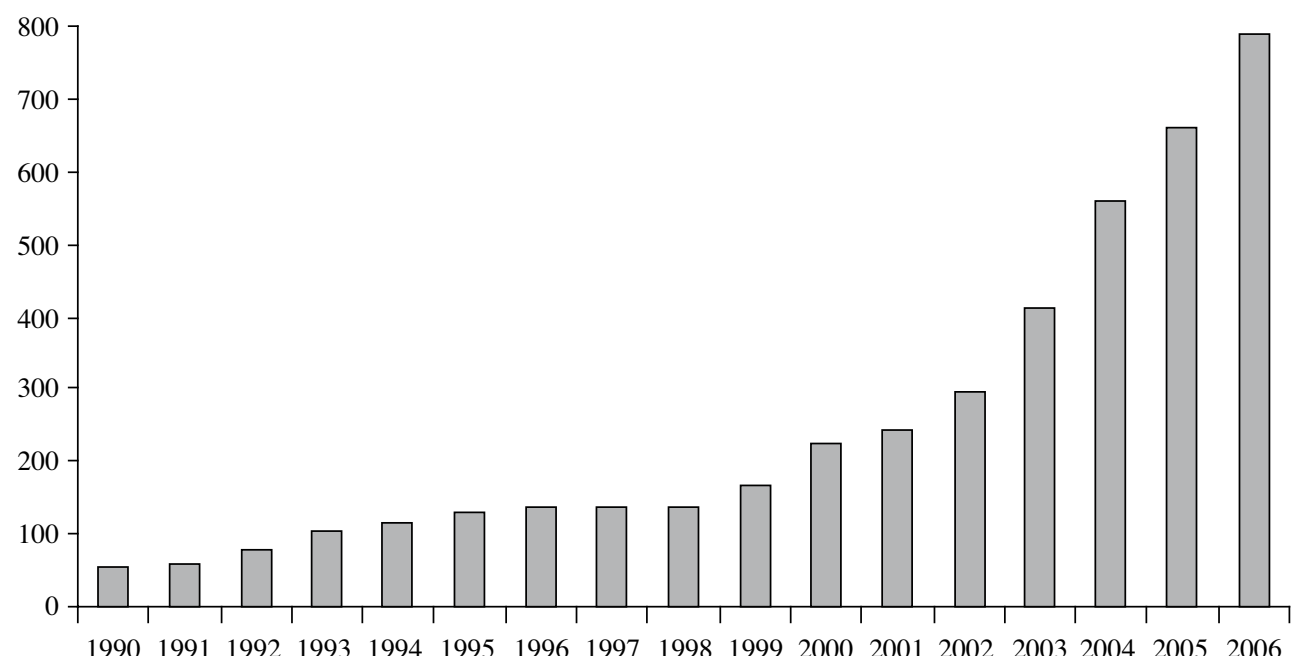

Source: prepared by the authors on the basis of figures from the United Nations Commodity Trade Database (COMTRADE).

FIGURE 2

China: manufacturing imports by value, 1990-2006 (Billions of dollars)

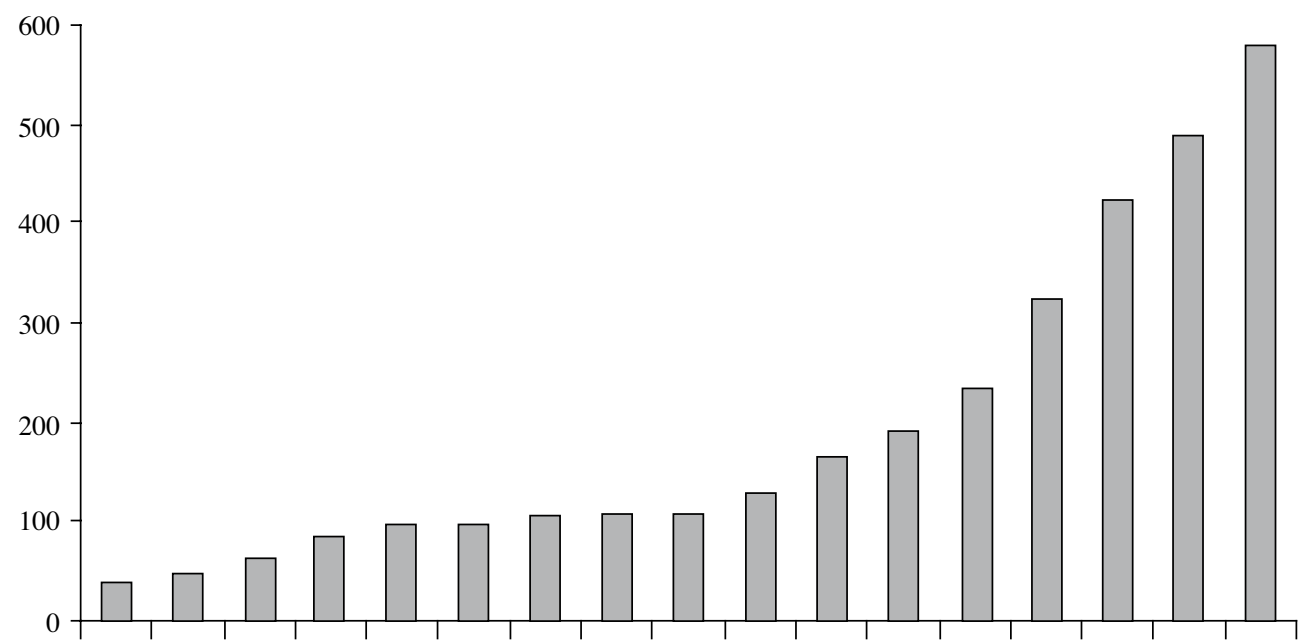

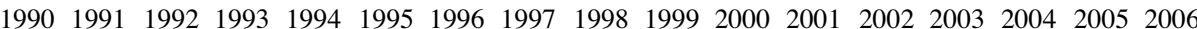

Source: prepared by the authors on the basis of figures from the United Nations Commodity Trade Database (COMTRADE). 
FIGURE 3

Total exports to China, by region, 1990-2006

(Billions of dollars)

Latin America and the Caribbean

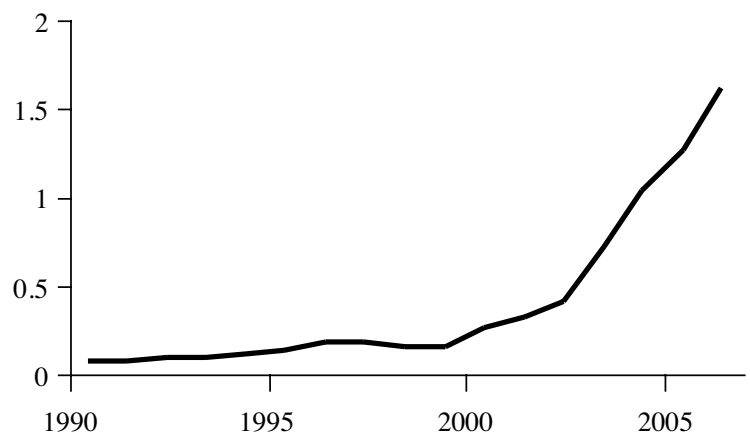

Europe

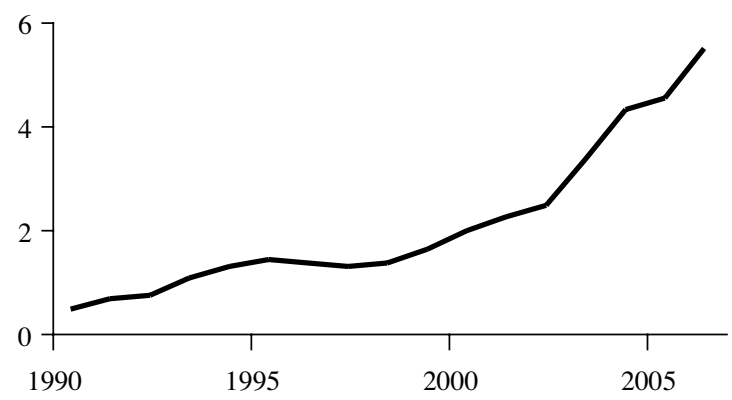

Africa

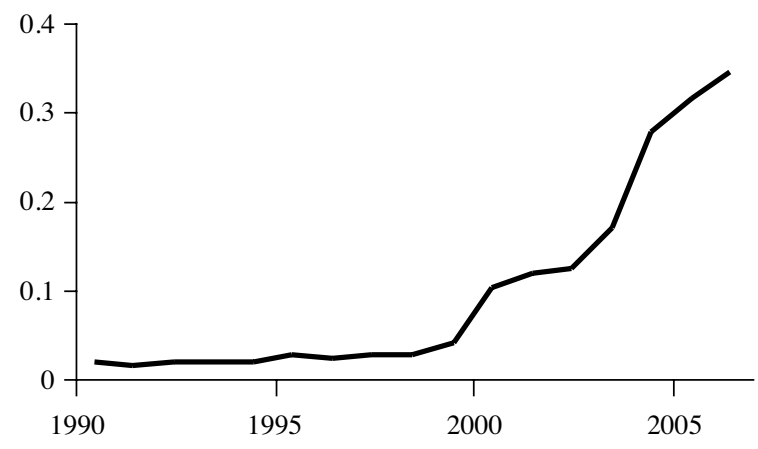

North America

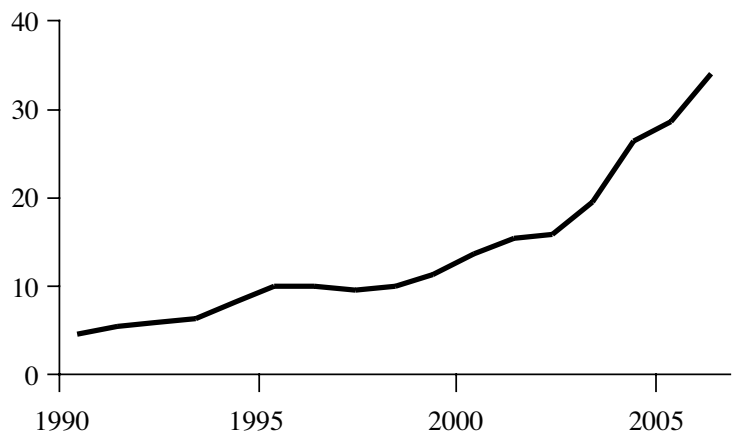

Asia

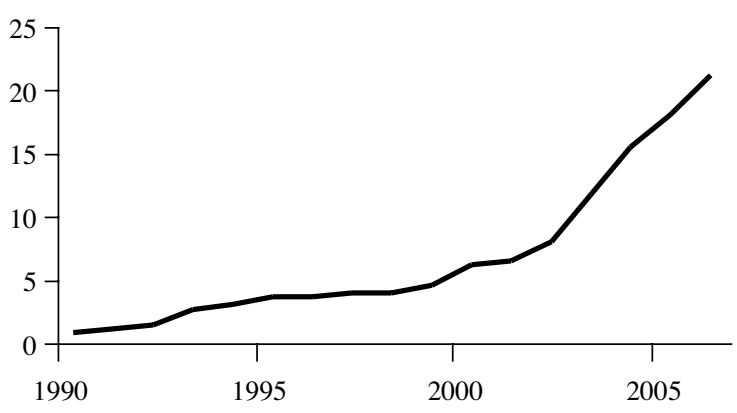

Oceania

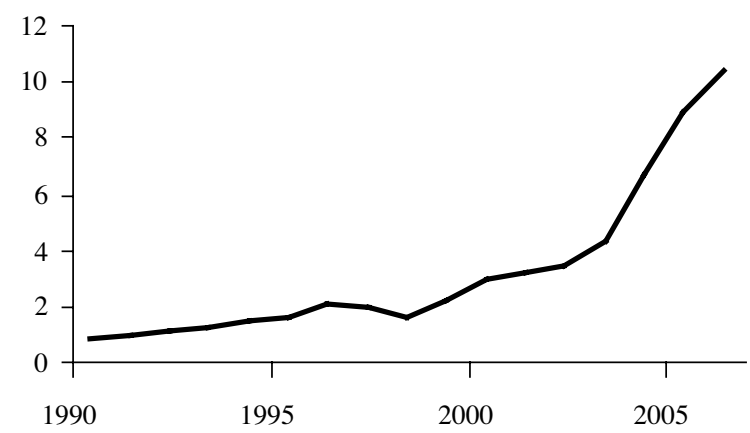

Source: prepared by the authors on the basis of figures from the United Nations Commodity Trade Database (COMTRADE). 
The question arises as to how this increase in Chinese trade has been distributed among the various regions of the world. Figure 3 shows that, broadly speaking, they have all taken advantage of the opportunities of the Chinese market and considerably increased the value of their exports to that country. Exports from North America rose from US\$ 8.03 billion to US\$ 66.96 billion; those of Asia from US\$ 11.54 billion to US\$ 315.84 billion; those of Oceania from US\$ 1.48 billion to US\$ 20.61 billion; those of Europe from US\$ 6.63 billion to US\$ 88.43 billion; those of Africa from US\$ 240 million to US\$ 6.53 billion; and those of Latin America and the Caribbean from US\$ 1.17 billion to US\$ 33.52 billion. Table 1 summarizes these results.

It is interesting to note the composition of exports to China and the relative importance of manufactured goods. ${ }^{2}$ Figure 4 shows the share of manufactures in each region's total exports. As can be seen, this share is highest in Europe, averaging 82\% in the 1990-2006 period. Substantial growth can also be seen in the case of Asia, where manufacturing exports to China

2 The classification of manufactured goods used in this section and the rest of the paper is the one devised by Leamer (1984) and is detailed in the annex. increased from $41 \%$ of the total in 1990 to $67 \%$ in 2006, while for North America they rose to $61 \%$ in 2006. The share of manufactured goods in the total exports of Oceania, Africa and Latin America and the Caribbean does not exceed $41 \%$, with the difference that this share has been increasing in Oceania and falling in Africa and Latin America and the Caribbean.

Broadly speaking, the evolution of manufacturing exports to China seems to be consistent with the idea that wealthier countries (i.e., those with more abundant physical and human capital) tend to have comparative advantages in the production of manufactured goods, as predicted by the traditional Heckscher-Ohlin model (Leamer, 1995). It would also seem to indicate that large countries like those of Europe and North America specialize in exporting manufactures (Perkins and Syrquin, 1989).

Table 2 gives a more detailed breakdown of the shares of the Latin American and Caribbean countries in Chinese imports of manufactures. The figures clearly show that, taken together, the region's economies account for a fairly small and declining proportion of the total. This includes the larger economies, whose share of Chinese manufactured goods imports also fell over the 1990s. The share of Brazil declined from $0.74 \%$ to $0.43 \%$, that of Argentina from $0.36 \%$ to $0.09 \%$ and that of Mexico from $0.34 \%$ to $0.31 \%$, before climbing back to $0.53 \%$ in 2006 .

TABLE 1

Exports to China, 1990-2006

\begin{tabular}{lcccc}
\hline Region & $\begin{array}{c}1990 \\
\text { (billions of dollars) }\end{array}$ & $\begin{array}{c}2006 \\
\text { (billions of dollars) }\end{array}$ & $\begin{array}{c}\text { Change 1990-2006 } \\
\text { (percentages) }\end{array}$ & $\begin{array}{c}\text { Annual growth rate } \\
\text { (percentages) }\end{array}$ \\
\hline North America & 8.03 & 66.96 & 734 & 13.89072 \\
Asia & 11.54 & 315.84 & 2637 & 20.38544 \\
Oceania & 1.48 & 20.61 & 1293 & 19.31248 \\
Europe & 6.63 & 88.43 & 1234 & 17.77355 \\
Africa & 0.24 & 6.53 & 2621 & 24.75957 \\
Latin America and the Caribbean & 1.17 & 33.52 & 2765 & 19.61709 \\
\hline
\end{tabular}

\begin{tabular}{|c|c|c|c|c|c|c|c|c|}
\hline \multirow{2}{*}{ All countries } & Total & Manufactures & Total & Manufactures & Total & Manufactures & Total & Manufactures \\
\hline & 53.3 & 41.5 & 791 & 576 & 1384 & 1288 & 16.36 & 15.59 \\
\hline
\end{tabular}

Source: prepared by the authors on the basis of figures from the United Nations Commodity Trade Database (COMTRADE).

a Geometric mean of annual growth rates during the 1990-2006 period. 
FIGURE 4

Manufacturing exports to China, by region, 1990-2006

(Percentages of the total)

Latin America and the Caribbean

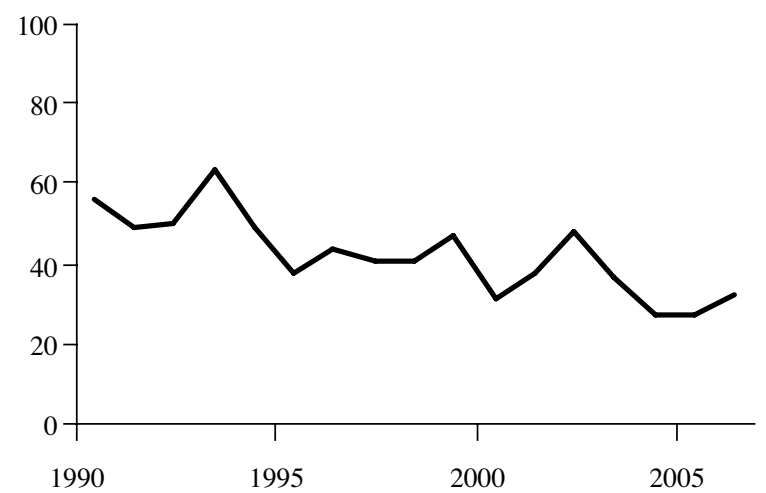

Europe

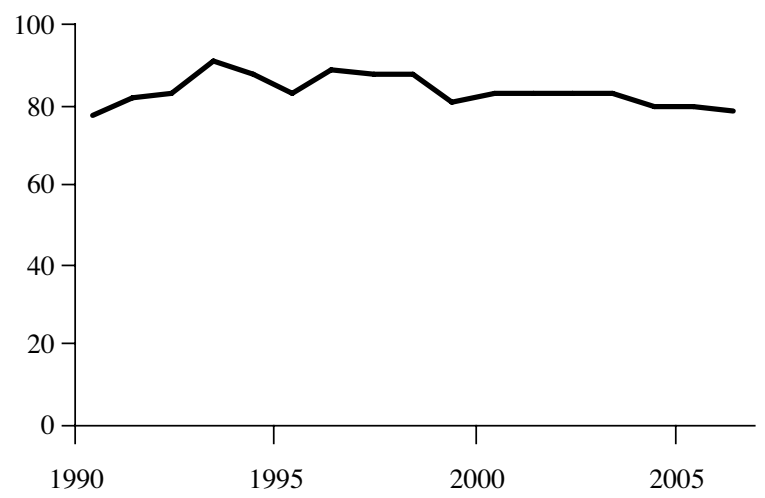

Africa

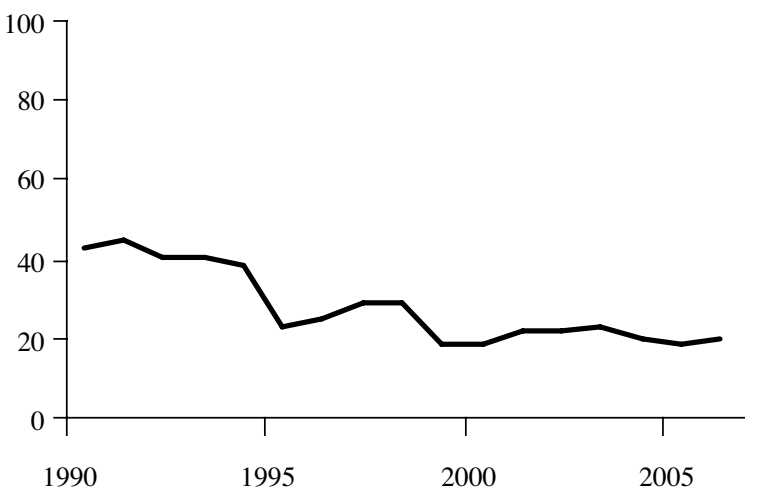

North America

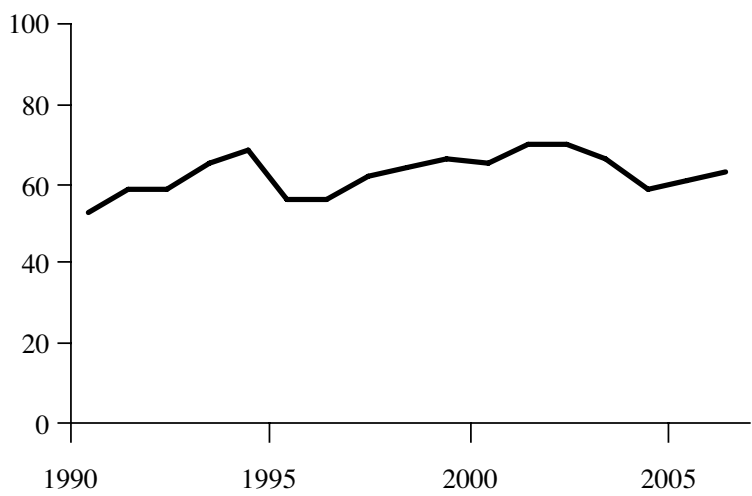

Asia

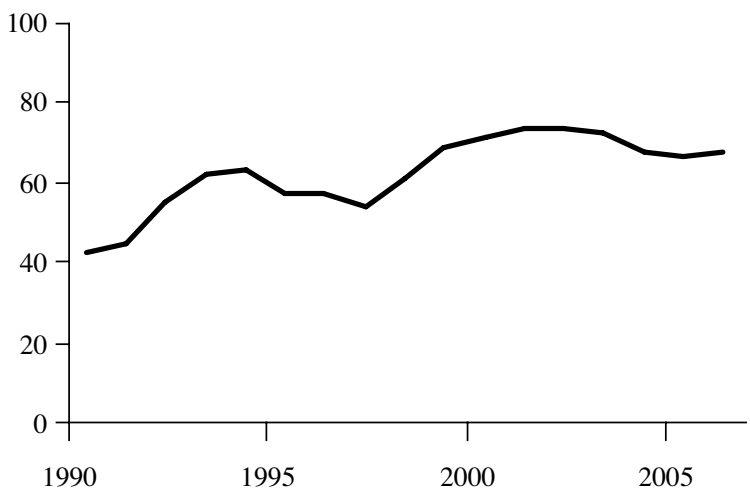

Oceania

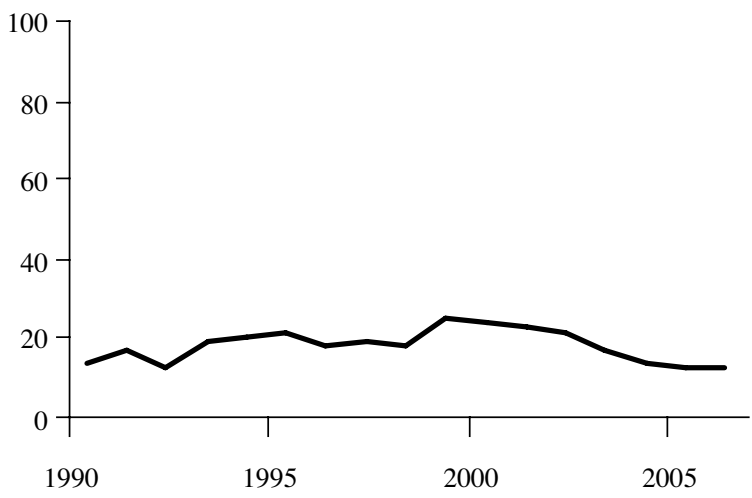

Source: prepared by the authors on the basis of figures from the United Nations Commodity Trade Database (COMTRADE). 
TABLE 2

Latin America and the Caribbean (selected countries): share of Chinese manufacturing imports, 1990-2006

(Average percentages for the period)

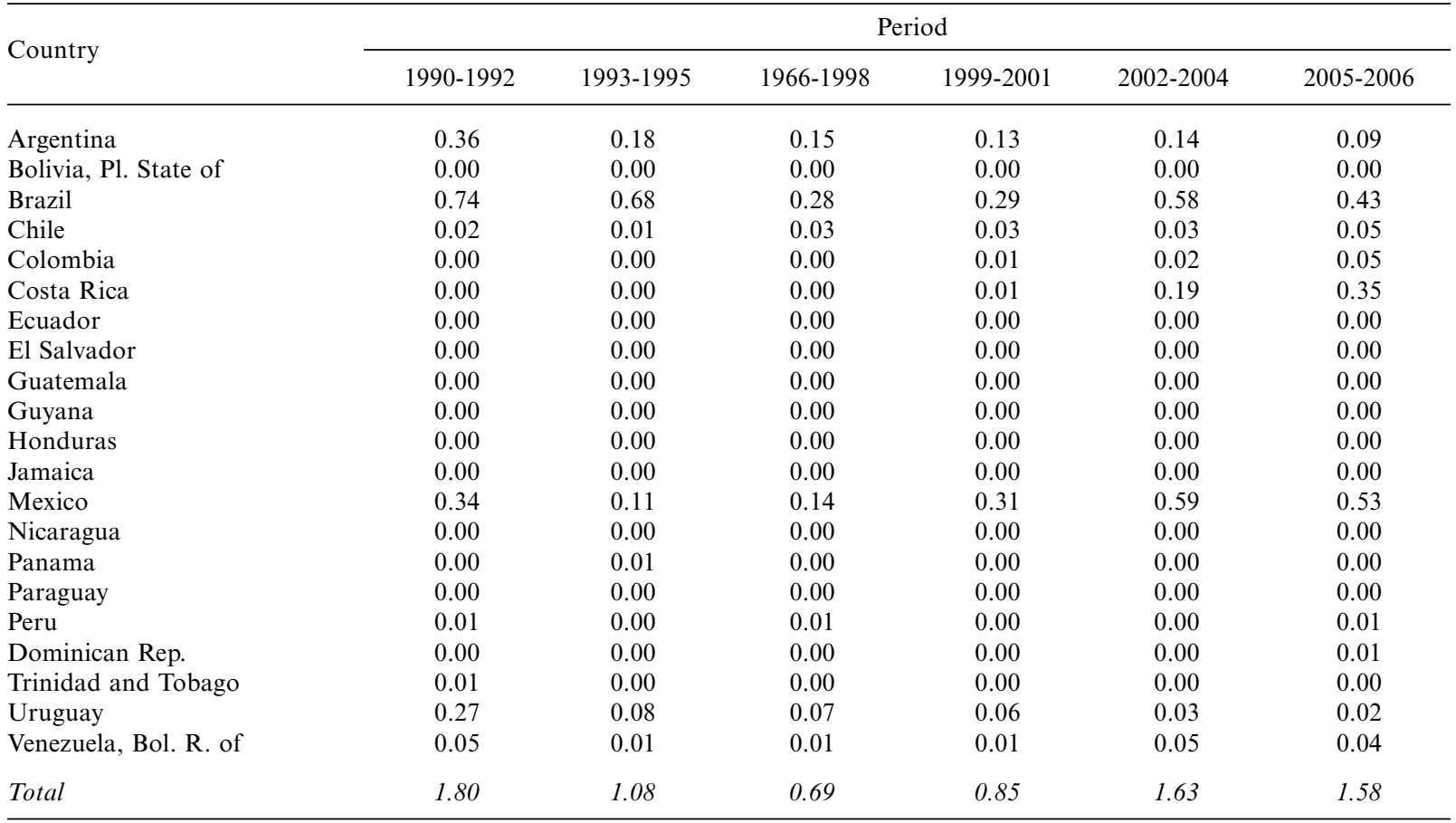

Source: prepared by the authors on the basis of figures from the United Nations Commodity Trade Database (COMTRADE).

\section{III}

\section{Empirical analysis}

\section{Model specification}

One of the most widely used and successful methodologies for studying the factors that determine trade in goods and its quantitative importance is the so-called gravity model. Originally proposed by Tinbergen (1962), this model has been extensively applied in the effort to answer questions about the effects of preferential agreements on bilateral trade (Baier and Bergstrand, 2007), the repercussions of countries' entry to the World Trade Organization (Rose, 2004) and the determinants of electronic commerce (Blum and Goldfarb, 2006), among other things.

The basic equation to be estimated is given by:

$$
X_{i j}=a_{0}\left(G D P_{i}\right)^{a_{1}}\left(G D P_{j}\right)^{a_{2}}\left(D I S T_{i j}\right)^{a_{3}} e^{a_{4} B O R D_{i j}+a_{5} \operatorname{LANG}_{i j}} \varepsilon_{i j}
$$

where $X_{i j}$ are exports from country $i$ to country $j$, $G D P_{i}$ is the output of country $i, D I S T$ is the distance between the two countries and BORD and $L A N G$ are categorical variables for countries that have a common border and language.

Taking the logarithm of both sides of equation (1), we get:

$$
\begin{gathered}
\ln \left(X_{i j}\right)=a_{0}+a_{1} \ln \left(G D P_{i}\right)+a_{2} \ln \left(G D P_{j}\right)+a_{3} \\
\ln \left(D I S T_{i j}\right)+a_{4} B O R D+a_{5} L A N G+\varepsilon_{i j}
\end{gathered}
$$

This study analyses the trade with China of 79 countries for which information on the 1990-2006 period is available (see annex 2 for the list of countries). The gravity model can be extended to determine the degree to which manufacturing exports to China 
are attributable to geographical factors that are unchanging over time (e.g., distance and a common border) and to other characteristics that do change (size of the country concerned, factor endowment and trade policy).

To analyse the effects of other geographic variables, factor endowments and tariff barriers to trade, equation (2) was extended by the addition of a categorical variable for exporting countries with an outlet to the sea. With regard to factor endowment, an estimate for human capital, physical capital and natural resources was included. The first two of these were measured by the education level of the over- 15 population and the capital ratio per worker, respectively, in the exporting country. Following Leamer (1987) and Schott (2003), the arable land area per worker was used as a measure of natural resource abundance. Trade barriers were represented by the average import tariff of each exporting country, ${ }^{3}$ a variable that does not reflect the barriers imposed by China on exports from other countries but rather the openness to trade of the country concerned.

The education, capital per worker and natural resource abundance variables were included in accordance with the implications of the HeckscherOhlin model, namely that a particular country has comparative advantages in the products that make intensive use of its most abundant factor of production. According to Rybczynski's theorem, assuming that manufactures are capital-intensive, differences in human and physical capital ought to be reflected in the volume of manufacturing exports going to China. In other words, countries with more capital ought to export more manufactures to the country. Extending the basic model, Leamer (1987) showed that an abundance of natural resources affected the development path of economies, making it less likely that they would have comparative advantages in the production of manufactured goods. In view of this, the land area per worker variable was included as a control.

The expected signs of all the explanatory variables are positive, with the exception of distance,

\footnotetext{
${ }^{3}$ All the variables mentioned were measured in logarithms.
}

average tariff and natural resource abundance. This is because a higher GDP, a common language and border, an outlet to the sea, a more highly educated workforce and a higher level of physical capital per worker are expected to result in a country exporting more manufactures.

Out of a total of 1,343 possible observations in the 79 countries, the results of 123 of them as regards exports to China were equal to zero. Given that these observations would be omitted if logarithms were applied, and relevant information thus lost, we adopted the commonly used alternative of defining the independent variable as $\ln (1+\mathrm{X})$.

\section{Data sources}

The trade data come from the United Nations Commodity Trade Database (COMTRADE), ${ }^{4}$ which contains detailed information on bilateral trade (exports and imports) by industry in four-digit subgroups that follow the Standard International Trade Classification (SITC) (Rev. 2). Given that our study concentrates on manufacturing exports during the 1990-2006 period, ${ }^{5}$ the classification of manufactured products developed by Leamer (1984) was used. Trade flows expressed in nominal dollars, following Rose (2004), were deflated by the United States wholesale price index.

Different information sources were used for the factor endowments of the various countries. Data on language, distance, access to the sea and contiguity came from the Research Centre for International Economics (CEPII). ${ }^{6}$ Figures for GDP and agricultural land were taken from the World Bank World Development Indicators, while the information on education and capital per worker is from Bosworth and Collins (2003). The data on import tariffs, used as a measure of openness to trade, come from the World Bank.

The descriptive statistics for all the variables used in the estimates are shown in table 3 .

\footnotetext{
${ }^{4}$ See [online] COMTRADE.un.org.

${ }^{5}$ Data are available from 1962, but analysis of the period prior to 1990 is less productive because of the small scale of trade flows with China.

${ }^{6}$ See [online] http://www.cepii.org/anglaisgraph/bdd/bdd.htm.
} 


\begin{tabular}{|c|c|c|c|c|c|}
\hline Variable & Observations & Mean & Stand. dev. & Minimum & Maximum \\
\hline Ln (1+exports) & 1343 & 8.77 & 5.00 & 0 & 18.17 \\
\hline Ln (distance) & 1343 & 9.11 & 0.54 & 6.91 & 9.86 \\
\hline Sea & 1343 & 0.86 & 0.35 & 0 & 1 \\
\hline Contiguity & 1343 & 0.03 & 0.16 & 0 & 1 \\
\hline Common language & 1343 & 0.03 & 0.16 & 0 & 1 \\
\hline Ln (arable land) & 1343 & -0.9 & 1.12 & -7.68 & 2.06 \\
\hline Ln (GDP) & 1264 & 24.52 & 2.01 & 19.91 & 30.03 \\
\hline Education & 1343 & 6.62 & 2.83 & 0.79 & 12.12 \\
\hline Ln (capital per worker) & 1343 & -5.07 & 2.77 & -13.82 & -1.2 \\
\hline Average tariff & 1343 & 13.02 & 10.28 & 0 & 94 \\
\hline
\end{tabular}

Source: World Bank; Research Centre for International Economics (CEPII); B. Bosworth and S.M. Collins, "The empirics of growth: an update", Brookings Papers on Economic Activity, vol. 34, No. 2, Washington, D.C., The Brookings Institution, 2003; United Nations Commodity Trade Database (COMTRADE).

\section{IV}

\section{Results of the estimates}

This section describes the results of the gravity model estimates. The cross-sectional estimates for different time periods are presented in table 4. Three-year intervals were used to reduce the effects of annual fluctuations (e.g., changes in certain product prices or temporary shocks) on the quality of the estimates. The option of producing the estimates from a data panel was discarded because some variables of interest, such as distance and common language, do not vary over time and would be absorbed by a fixed effect for the exporting country.

The variable that measures the distance between the exporter and China is negative and statistically significant in all the specifications, and the parameter value ranges from -1.98 to -1.47 . As was to be expected, a greater distance from China increases trading costs, which translates into lower exports to that economy. To gain a quantitative idea of the importance of distance according to these estimates, the difference between the exports of a Latin American country and an Asian one was calculated using the average distance of each group from China and the parameter corresponding to the last period estimated. In this case, the difference in exports is given by:

$$
\partial \operatorname{Ln}(X)=-1.47\left[\ln D_{L A}-\ln D_{A S I A}\right]=1.91
$$

This means that if the average Latin American country were the same distance from China as the average Asian country, it could increase its exports by over $190 \%$.

As expected, the fact of having a common language with China exercises a positive influence and its contribution is significantly different from zero from the second period of analysis onward. These results are compatible with the findings of earlier studies that countries with a common language trade more with one another (Rose, 2004).

The contiguity variable is not significant in any of the years studied. The expected sign was positive, since the lower costs of doing business between neighbouring countries tends to favour reciprocal trade. However, only two of the 79 countries in the sample have a border with China: India and Pakistan. Another geographic factor that appears to have no effect on manufacturing exports is whether the exporting country has an outlet to the sea.

The results indicate that the abundance of natural resources, measured in this case by the land to capital ratio, does not appear to have a significant effect on manufacturing exports to China in any of the years studied. Although it is possible that there may be more suitable variables for measuring natural resource 
TABLE 4

Cross-sectional estimates, 1990-2006

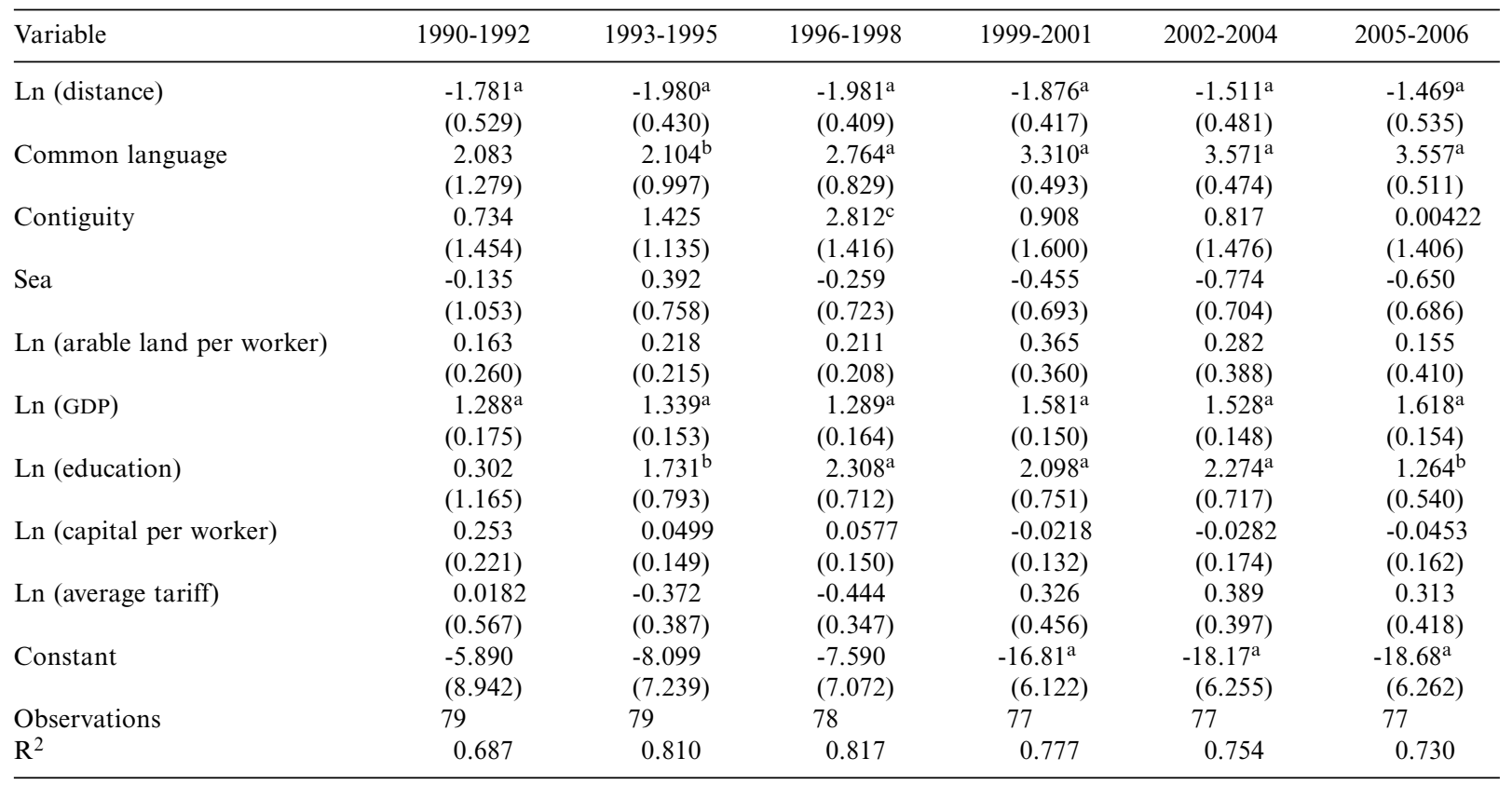

Source: prepared by the authors.

N.B.: Robust standard errors in parentheses.

a $\quad \mathrm{p}<0.01,{ }^{\mathrm{b}} \mathrm{p}<0.05,{ }^{\mathrm{c}} \mathrm{p}<0.1$.

endowments, there was no sample of countries for which any were available over the time period analysed in this study.

The size of the exporting country, as measured by GDP, is positive and statistically significant in all the periods studied. This size effect could be due to the presence of economies of scale in the production of manufactures (Perkins and Syrquin, 1989), but it could also be explained by the fact that larger countries tend to export a greater volume of goods of every kind (Hanson and Xiang, 2004). To place the economy size results in context, we may consider two countries like Trinidad and Tobago and Brazil, which are among the smallest $10 \%$ and the largest $10 \%$ of the sample, respectively. Using the estimates for the last period, the percentage difference between the two countries' manufacturing exports can be calculated as:

$$
\partial \operatorname{Ln}(X)=-1.618\left[\ln \left(G D P_{B r a z i l}\right)-\operatorname{Ln}\left(G D P_{T \& T}\right)\right]=6.53
$$

These figures indicate that economy size translates into marked differences in manufacturing export capacity.
On the whole, the results seem to be fairly consistent with traditional international trade theory. The variable measuring human capital abundance is positively related with manufacturing exports. Workforce education is positive and significant in all but the first period studied. In this case, exporting differences can be illustrated by looking at the average education level of Latin American and European countries. Given that the parameters tend to vary from one period to another and in some cases are not significant, we used the mean of the four periods analysed. The results indicate that if the average Latin American country had the same level of education as the average European country, its exports would be almost $35 \%$ greater. The capital per worker variable, meanwhile, proved non-significant in all the periods studied.

Lastly, the results for openness to trade as measured by average import tariffs do not indicate a tendency for more open economies to export a greater volume of manufactured goods to China. These results obviously need to be analysed with care. For one thing, the estimates did not consider other trade barriers such as non-tariff restrictions, as information on these was not available for the country sample used. 
However, given that most countries have opened up their economies over recent decades, this result could be consistent with the idea that tariff barriers are no longer a significant impediment to manufacturing

\section{V}

\section{Conclusions}

The economic growth of China, and the significant role the country has come to play as a major consumer of raw materials and more highly processed goods such as manufactures, has opened up great opportunities for exporting countries everywhere. This large and growing economy represents an increasingly important source of potential demand for developing countries with growth strategies based on exploiting comparative advantages and participating in international markets.

The purpose of this study has been to identify the determinants of manufacturing exports to China by means of a gravity model incorporating variables related to countries' geographical conditions, factor endowment and trade policies.

The findings reveal the importance of three fundamental elements: the distance from the exporting country to China, its factor endowment and the size of its economy. Given that this last component is relatively exogenous to the policies the economic authorities can apply, discussion of the results centres mainly on aspects relating to distance and factor endowment.

Although the distance factor is also exogenous to the economy, there are policies that can reduce its negative effects on trade, and specifically on manufacturing exports. Indeed, the negative repercussions of transport costs on trade mean that the countries furthest from China and other centres of global trade have a natural disadvantage that needs to be offset by improvements to the relevant infrastructure. The challenge here is even greater for the Latin American economies than for those more favourably located. Public policies to improve highway infrastructure, particularly in the case of roads connecting manufacturing centres to the ports from which exports are shipped, and to upgrade equipment and modernize and mechanize ports and airports, could have a substantial impact. Again, a policy of awarding concessions to build the necessary public infrastructure would circumvent constraints on investment capital, which is in particularly short supply in some of the region's countries. Also exports. Indeed, Wacziarg and Horn-Welch (2003) show that between 1990 and 2000 the percentage of economies that can be described as open to international trade rose from just over $40 \%$ to $73 \%$. beneficial would be policies to improve efficiency and remove corruption in customs systems and export certification mechanisms, which sometimes represent an additional cost for exporters. Accordingly, policies and programmes that pursue transparency in public services, the training of State officials and the promotion and creation of professionalized public services, with careers based on qualifications and merit and independent of political influence, would go a long way towards solving many of the problems of inefficiency that translate into high costs for exporters. In countries where the transportation of products and merchandise has become increasingly insecure because of a rise in robberies and hold-ups of transporters, adopting policies to improve controls and strengthen security and the police could bring down the costs incurred by exporters, especially for manufactures, since it is these that are most frequently targeted by this type of crime.

Lastly, the findings relating to the effects of factor endowments on manufactured goods exports reveal the challenges that less developed economies will have to meet if they are to change their specialization patterns. To become exporters of manufactures, they need to increase their human capital endowment. For many developing nations, this means formulating policies to improve access to all levels of education and training. In most cases, it also means increasing the incomes of the poorest quintiles and designing and implementing public policies to create the infrastructure and childcare and nursery facilities needed for mothers in the more disadvantaged quintiles to enter the workforce and for children to have access from an early age to a stimulating environment that nurtures their learning skills. Looking ahead, however, it is education quality that seems to have become the most critical variable for the region, particularly in countries that have already made progress in this area. This represents a major public policy challenge, since improving education has proven to be a particularly testing task even in developed 
countries where resources are far less constrained than in Latin America. There are similar challenges in the area of training, and especially on-the-job training. Here it would be advisable for the public and private sectors to formulate joint policies with a view to designing and implementing programmes that can bring real improvements to countries' competitive advantages, as these can be enhanced by providing tax credits to firms and production sectors that expend effort and resources on worker training and specialization.

(Original: Spanish)

ANNEX 1

Leamer's aggregates

\begin{tabular}{lr}
\hline Manufacturing aggregate & SITC \\
\hline Labour-intensive & 66 \\
Non-metal minerals & 82 \\
Furniture & 83 \\
Travel goods, handbags & 84 \\
Articles of apparel & 85 \\
Footwear & 89 \\
Miscellaneous manufactured articles & 91 \\
Postal packaging, not classified & 93 \\
Special transactions, not classified & 96 \\
Coins (non-gold) & 96
\end{tabular}

Capital-intensive

Rubber

Textile yarn, fabric

Iron and steel

Manufactured metal n.e.s.

Sanitary fixtures and fittings

Machinery

Power generating

Specialized

Metalworking

General industrial

Office and data-processing

Telecommunications and sound

Electrical

Road vehicles

Other transportation vehicles

Professional and scientific instruments

Photographic apparatus

Firearms and ammunition

Chemicals

Organic

Inorganic

Dyeing and tanning

Medicinal, pharmaceutical products

Essences and perfumes

Fertilizers

Explosives and pyrotechnics

Artificial resins and plastics

Chemical materials n.e.s.

Source: E.E. Leamer, "The Heckscher-Ohlin model in theory and practice”, Princeton Studies in International Finance, No. 77, Princeton, Princeton University, 1995. 
ANNEX 2

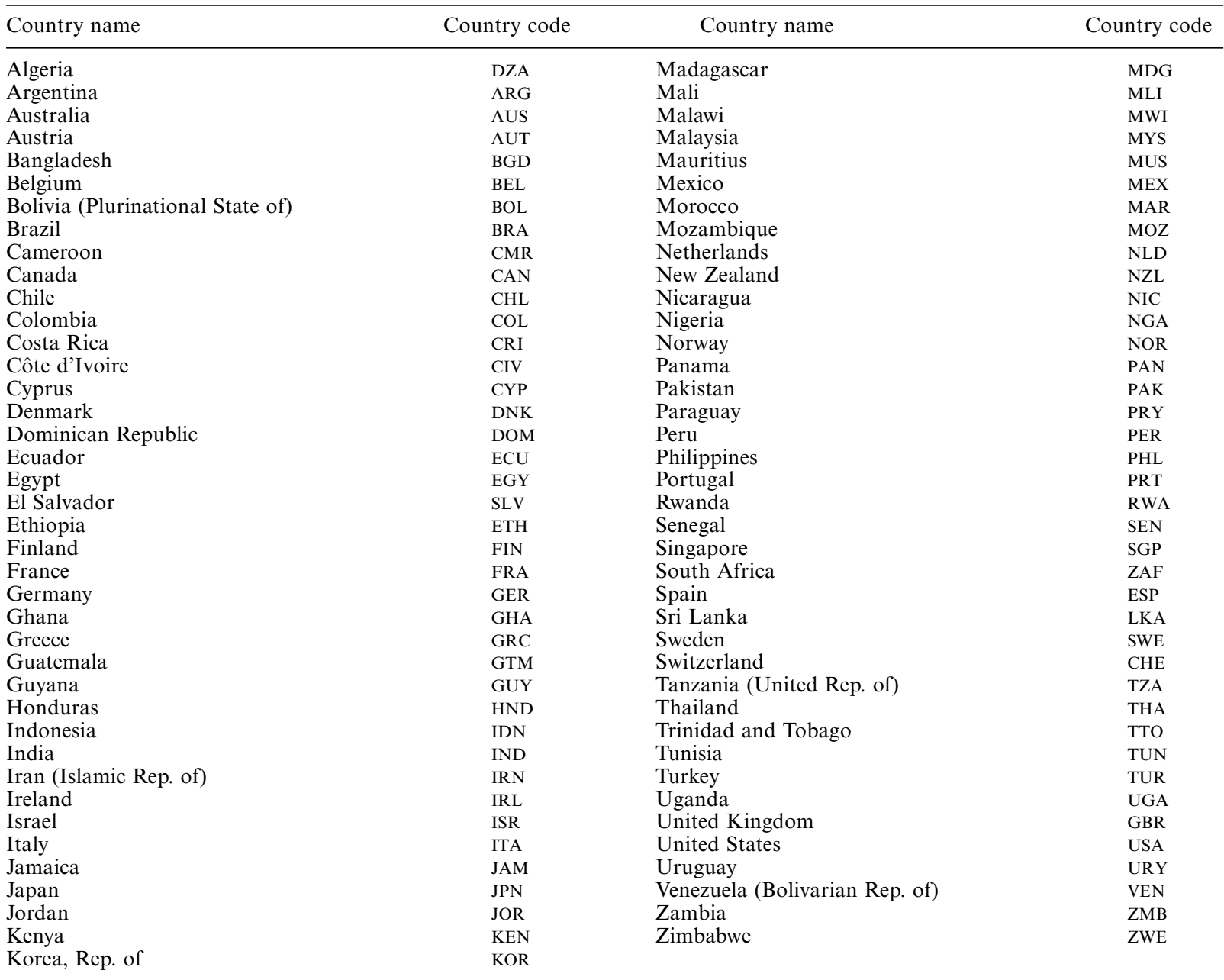

Source: prepared by the authors.

ANNEX 3

Main variables used

\begin{tabular}{lll}
\hline Variable & \multicolumn{1}{c}{ Description } & \multicolumn{1}{c}{ Primary data source } \\
\hline $\mathrm{X}$ & Exports & COMTRADE \\
DIST & Distance & CEPII \\
SEA & Outlet to sea & CEPII \\
BORD & Contiguity & CEPII \\
LANG & Language & CEPII \\
LAND & Arable land & World Bank, World Development Indicators \\
WFORCE & Workforce & World Bank, World Development Indicators \\
$\mathrm{R}$ & Arable land per worker & World Bank, World Development Indicators \\
EDU & Years of education & Bosworth and Collins (2003) \\
KL & Capital per worker & Bosworth and Collins (2003) \\
OPEN & Import tariffs & World Bank \\
\hline
\end{tabular}

Source: World Bank; Research Centre for International Economics (CEPII); B. Bosworth and S.M. Collins, "The empirics of growth: an update", Brookings Papers on Economic Activity, vol. 34, No. 2, Washington, D.C., The Brookings Institution, 2003; United Nations Commodity Trade Database (COMTRADE).

N.B.: The variables in the model regressions are expressed in natural logarithms.

a Data available [online] http://go.worldbank.org/LGOXFTV550. 


\section{Bibliography}

Álvarez, R. and J.R. Fuentes (2006), "Paths of development, specialization, and natural resources abundance", Working Paper, No. 383, Santiago, Chile, Central Bank of Chile, December.

Baier, S.L. and J.H. Bergstrand (2007), "Do free trade agreements actually increase members' international trade?", Journal of International Economics, vol. 71, No. 1, Amsterdam, Elsevier.

Blázquez-Lidoy, J., J. Rodríguez and J. Santiso (2006), "Angel or demon? China's trade impact on Latin American countries", CEPAL Review, No. 90 (LC/G.2323-P), Santiago, Chile, December.

Blum, B. and A. Goldfarb (2006), "Does the Internet defy the law of gravity?", Journal of International Economics, vol. 70, No. 2, Amsterdam, Elsevier.

Bosworth, B. and S.M. Collins (2003), "The empirics of growth: an update", Brookings Papers on Economic Activity, vol. 34, No. 2, Washington, D.C., The Brookings Institution.

Claro, S. (2006), "Implications of China's emergence in the global economy for Latin America and the Caribbean region. Background paper: Chile", Integration and Trade, No. 24, Buenos Aires, Institute for the Integration of Latin America and the Caribbean (INTAL)/Inter-American Development Bank (IDB), January/July.

Devlin, R., A. Estevadeordal and A. Rodríguez-Clare (2006), The Emergence of China: Opportunities and Challenges for Latin America and the Caribbean, Washington, D.C., David Rockefeller Center for Latin American Studies/InterAmerican Development Bank.

Feenstra, R.C. and others (2004), "World trade flows: 1962-2000", NBER Working Paper, No. 11040, Cambridge, Massachusetts, National Bureau of Economic Research.

Hanson, G. and C. Xiang (2004), "The home market effect and bilateral trade patterns", American Economic Review, vol. 94, No. 4, Nashville, Tennessee, American Economic Association.
Leamer, E.E. (1995), "The Heckscher-Ohlin model in theory and practice”, Princeton Studies in International Finance, No. 77, Princeton, Princeton University.

(1987), "Paths of development in the three-good n-factor general equilibrium model", Journal of Political Economy, vol. 95, No. 5, Chicago, University of Chicago Press.

(1984), Sources of International Comparative Advantage: Theory and Evidence, Cambridge, Massachusetts, The MIT Press.

Lehmann, S., D. Moreno and P. Jaramillo (2007), "China, commodity prices and Latin American performance: a few stylized facts", Working Paper, No. 424, Santiago, Chile, Central Bank of Chile, August.

Mesquita Moreira, M. (2007), "Fear of China: is there a future for manufacturing in Latin America?", World Development, vol. 35, No. 3, Amsterdam, Elsevier.

Perkins, D.H. and M. Syrquin (1989), "Large countries: the influence of size", Handbook of Development Economics, vol. 2, Amsterdam, Elsevier.

Rosales, O. and K. Kuwayama (2007), "Latin America meets China and India: prospects and challenges for trade and investment", CEPAL Review, No. 93 (LC/G.2347-P), Santiago, Chile.

Rose, A. (2004), "Do we really know that the wTO increases trade?", American Economic Review, vol. 94, No. 1, Nashville, Tennessee, American Economic Association.

Schott, P.K. (2003), "One size fits all? Heckscher-Ohlin specialization in global production", American Economic Review, vol. 93, No. 3, Nashville, Tennessee, American Economic Association.

Tinbergen, J. (1962), Shaping the World Economy: Suggestions for an International Economic Policy, New York, The Twentieth Century Fund.

Wacziarg, R. and K. Horn Welch (2003), "Trade liberalization and growth: new evidence", NBER Working Paper, No. 10152, Cambridge, Massachusetts, National Bureau of Economic Research, December. 